\title{
CAREX SECALINA (CYPERACEAE), A SPECIES CRITICALLY ENDANGERED IN EUROPE: FROM PROPAGULE GERMINATION TO PROPAGULE PRODUCTION
}

\author{
WAldemar ŻUKOWSKi ${ }^{1}$, MARLENA LembicZ ${ }^{1}$, PAWEŁ OLEJNICZAK ${ }^{2}$, \\ AGNIESZKA BOGDANOWICZ ${ }^{1}$, JULIAN CHMIEL ${ }^{1}$, ARTUR ROGOWSKI ${ }^{1}$ \\ ${ }^{1}$ Department of Plant Taxonomy \\ Adam Mickiewicz University \\ Niepodległości 14, 61-713 Poznań, Poland \\ e-mail: zukowski@amu.edu.pl \\ ${ }^{2}$ Institute of Nature Conservation \\ Polish Academy of Science \\ Mickiewicza 33, 31-120 Kraków, Poland \\ e-mail: ojejniczak@iop.krakow.pl
}

(Received: April 19, 2004. Accepted: June 3, 2004)

\begin{abstract}
ABCTRACT
The size and reproduction ability of the three field populations of Carex secalina Willd. ex Wahlenb. have been assessed. In the parallel garden study selected traits from the life history of the species have been studied, such as age at first reproduction, fertility, the size of seeds, their germination ability and size of seedlings. The populations of C. secalina discovered in Poland in 2000 are characterised by small abundance and small area. All individuals from the three populations in the garden produced generative shoots in the third year of life. Statistically significant differences between the populations were found in the production of shoots with unisexual spikes and bisexual ones, the latter had not been reported in the hitherto literature on the species. The seeds started germinating after a 6-months rest. The first seedlings were observed in the first decade of May. The largest seedlings were noted in the population producing the smallest seeds. The results contribute to explaining the renewal of the populations of this species in the field.
\end{abstract}

KEY WORDS: abundance, germination, seedlings, age at first reproduction, fertility, field and greenhouse study, halophyte, Carex secalina, Cyperaceae, endangered species.

\section{INTRODUCTION}

Carex secalina Willd. ex Wahlenb. is a halophyte classified as critically endangered or endangered in a few European countries (Maglocký and Feraková 1993; Ludwig and Schnittler 1996; Holub and Procházka 2000; Chmiel et al. 2001). It is protected under the Convention on the Conservation of European Wildlife and Natural Habitats, adopted in Bern in 1979. In Poland at the beginning of the 20th century $C$. secalina occurred in 9 localities in Kujawy region (Bock 1908) and in Rąbin near Inowrocław it was observed till the end of 1930s (Urbański 1930; Wodziczko et al. 1938).

The study on the flora and halophilous vegetation carried out by Wilkon-Michalska (1963) did not confirm the presence of this species in the above-mentioned localities. For over 40 years $C$. secalina was considered extinct on the scale of the region (Wilkoń-Michalska 1963; Żukowski and Jackowiak 1995) and in the whole country (Zarzycki and Szelag 1992; Zając and Zajac 1993). In 2000 the presence of this species in two of the localities of its earlier occurrence Jacewo and Turzany was confirmed. A new locality of the species occurrence was found in Dulsk. In the latest issue of the Polish Red Data Book of Plants the species $C$. secalina has been classified as critically endangered (Chmiel et al. 2001).

In 2000 monitoring of the population of $C$. secalina in the field was started and simultaneously the species was grown in garden conditions. This procedure has become a standard for the species from Red Data Books. It is generally assumed that comprehensive protection of the environment should take into regard biodiversity, i.e. should be based on assessment of the level of biotic variation from gene to population (Myers et al. 2000; Purvis and Hector 2000). This type of information enables recognition of such attributes of the species as its evolutionary history, life history, genetic structure, reproductive system and population dynamics. 
To the best of our knowledge there are no works on the life history of $C$. secalina in literature. Such basic questions as what is the lifetime of the species, what is the age it starts reproduction, does it produce seeds capable of germination or forms a seed bank and so on have been hitherto unanswered. Therefore, at the present stage we do not know, which abiotic and biotic factors should be considered to put forward hypotheses explaining the present type of range of this species and justifying its inclusion in the Red Data Book.

The paper presents a part of the results, which enable answering the following questions: (1) what is the present state of $C$. secalina population in Poland (its area, abundance and reproduction), (2) are its seeds capable of germination, (3) at what age does it start reproduction and what is the fertility of its individuals, (4) do the populations of $C$. secalina differ in the two key elements in the life of each plant that is the size of the seeds and the seedlings?

The results are also expected to help answering two general questions: (1) whether the occurrence of $C$. secalina in small isolated populations over the whole range including Poland is a result of withdrawing of the taxon or should be considered in the aspect of metapopulation processes, and (2) what is the origin of the populations (seed bank or new diaspores) especially in the locality never reported earlier.

\section{MATERIAL AND METHODS}

\section{Species studied}

Carex secalina Willd. ex Wahlenb. 1803 is one of the five species representing the section Secalinae (O. Lang) Kuk. 1909 in the subgenus Carex and family Cyperaceae (Egorowa 1999). It occurs in Western, Northern and Middle Europe and Central Asia (Meusel et al. 1965). Over the whole range it is considered a rare species, growing in scattered and isolated localities in Europe and Asia (Fig. 1). In the European part it is most often met in South Germany,
Austria, Hungary, in southern parts of the Ukraine and Russia at the mouth of the Dnieper River to the Black Sea and the Volga River to the Caspian Sea. The localities from the southern Ural Mountains are related to the southSiberian part of the range. The Asiatic part of its area is composed of isolated localities scattered from the South Ural Mountains in the west, through Kazakhstan, to Lake Baikal in the east (Meusel et al. 1965, Egorova 1999). C. secalina is a tuft-making perennial of iterative growth (Fig. 2 ). It is a monoecious sedge. Each individual produces generative shoots with male and female spikes. At the top of the shoots there are 2-3 male spikes and below them there are single female spikes.

\section{Field study}

The study was begun in 2000 in which the first (Dulsk N 52 $45.436^{\prime}$; E $18^{\circ} 21.222^{\prime}$ ) of the three localities of this species were found. Analysis of population abundance and fertility of individuals was made at the turn of June and July 2000 , also in the two newly discovered localities (Jacewo - N 52 47.276'; E $18^{\circ} 20.301^{\prime}$ and Turzany N 52 47.286'; E $\left.18^{\circ} 20.338^{\prime}\right)$. Henceforth we will assume the following notation: population A - Dulsk, population $\mathrm{B}$ - Jacewo and C - population in Turzany. Populations $\mathrm{A}$ and $\mathrm{B}$ are related to wet saline pasture and co-exist with a large group of halophylous species (Fig. 3). Population $\mathrm{C}$ grows in man-made habitats with in the limits of a farm on a substrate containing slag and debris, and co-exists with a group of ruderal species (Fig. 3).

At each of the three localities a study area covered the whole area of the population. In the area elementary study plots of $1 \mathrm{~m}^{2}$ were delimited and in each study plot all individuals were recorded. On each individual the number of generative shoots with mature utricles was calculated. The length and width of the utricles and the length and width of the fruits were measured under a Brünel microscope to an accuracy of $0.05 \mathrm{~mm}$. Because of problems with getting the fruits out of the utricles their measurements were made after $24 \mathrm{~h}$ flooding of the whole utricles in water.

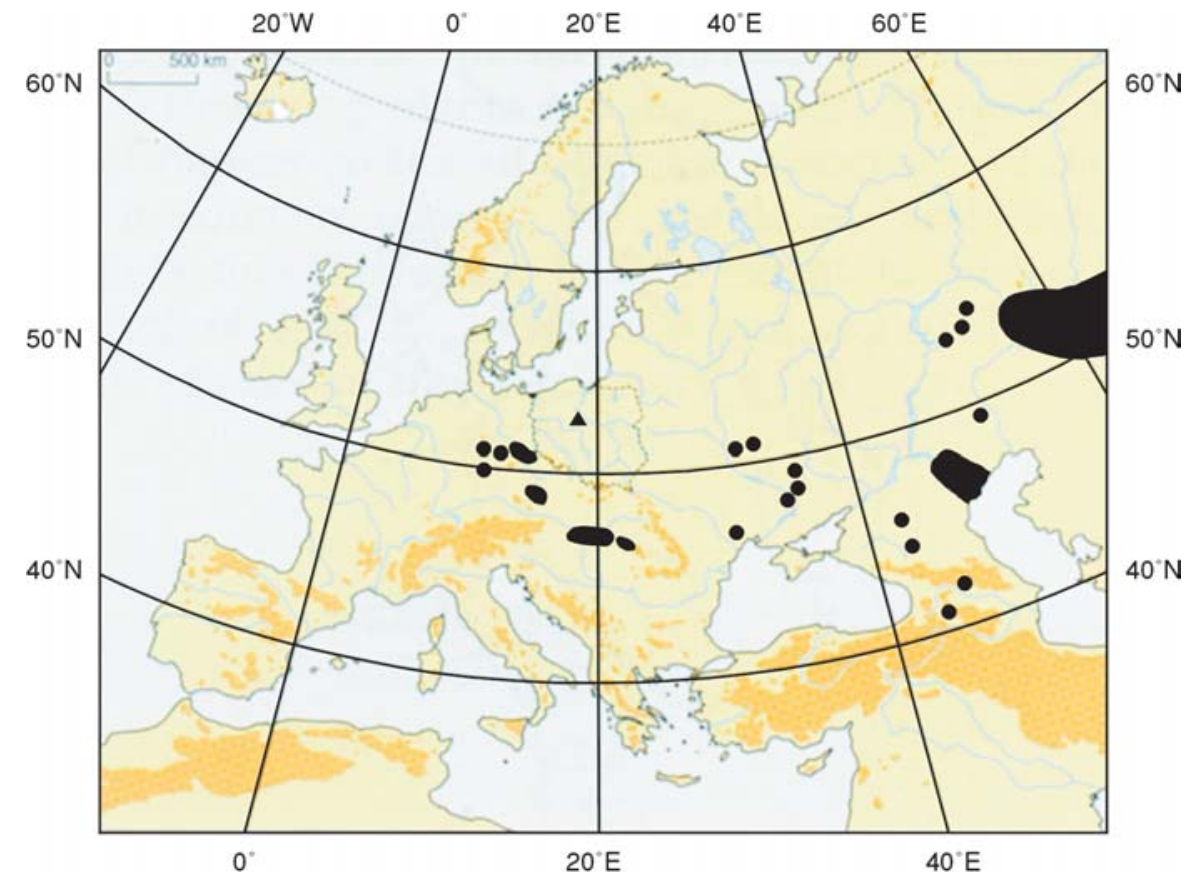

Fig. 1. Distribution of Carex secalina in Europe and Asia (after Meusel et al. 1965). 

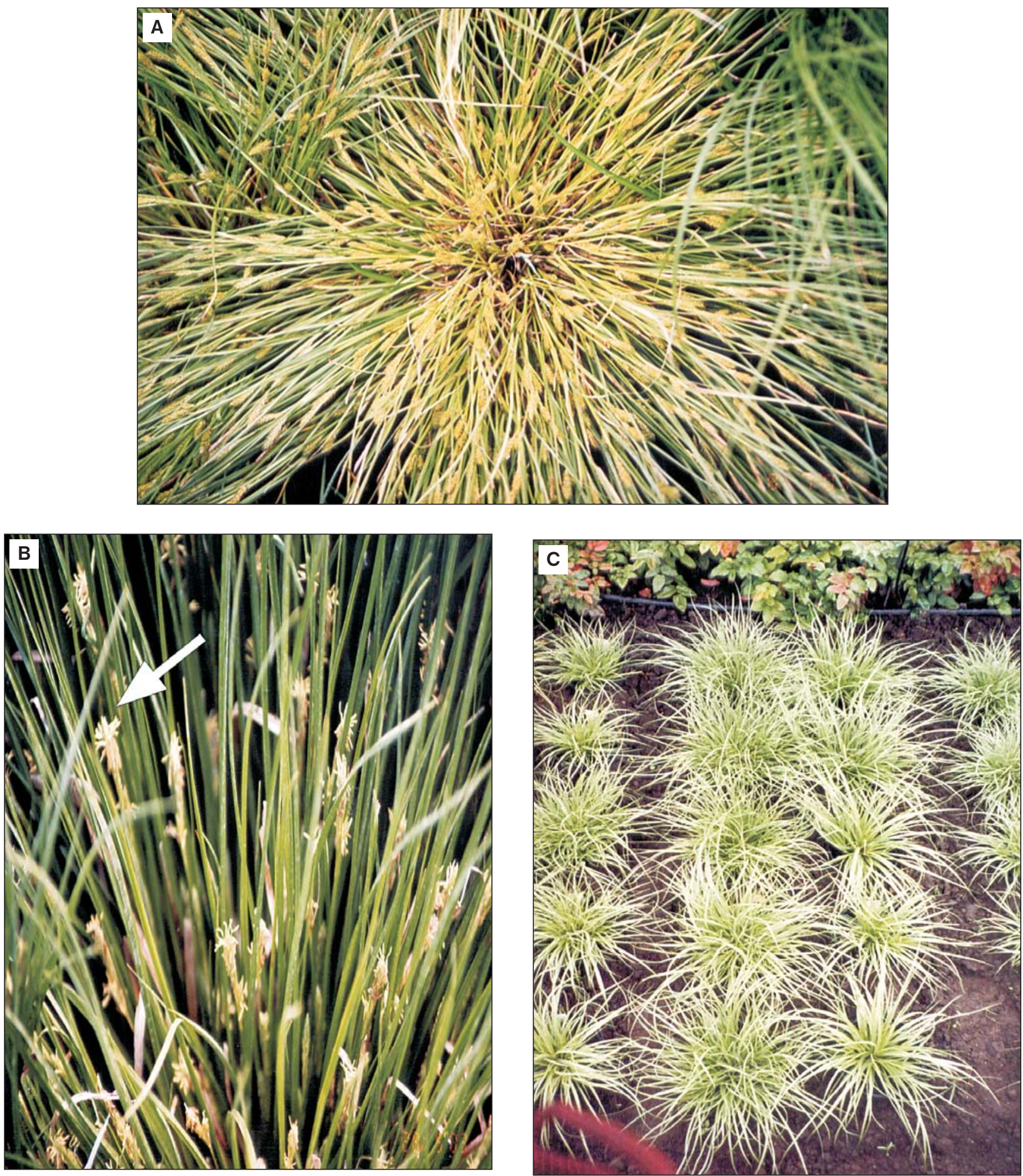

Fig. 2. Carex secalina: A - a tuft of Carex secalina in an inland saline in Poland, B - female and male spikes of (the arrow indicates anthers of male spikes), C - one-year old tufts of C. secalina in the garden.

Greenhouse study

Experiment 1 - assessment

of seeds' germination ability and size of seedlings.

The seeds were collected in July 2000 in the field and were sown in October the same year in pots of $12 \mathrm{~cm}$ diameter at a depth of $2 \mathrm{~cm}$. Altogether about 400 seeds from each population were sown. From May 6th to 31st, 2001, the appearing seeds of the species were recorded. In July, 60 seedlings representing each population were selected and the lengths of their aboveground and underground parts were measured.

\section{Experiment 2 - assessment}

of the age of starting reproduction and fertility:

90 of the seedlings obtained in the first experiment in groups of 30 representing each population were planted into separate pots. Following this method we could be sure that each pot contained a genet, that is an individual co- 
Trifolium fragiferum

Bulboschoenus maritimus

Halophytes

Ruderals

Glaux maritima

Puccinellia distans

Lotus tenuis

Plantago major
Lolium perenne
Taraxacum officinale

B

Trifolium fragiferum

Puccinellia distans
Puccinellia distans
Plantago maior

Lolium perenne

Taraxacum officinale
Matricaria suaveolens

Polygonum aviculare

Matricaria inodora

Atriplex prostrata

Lepidium ruderale

Fig. 3. Composition of species coexising with Carex secalina. Only species with more than $25 \%$ cover are listed here.

ming from a single zygote. The bottoms of all pots were removed and the pots were placed in soil. The cultivation is at present 3 years old. In the last decade of June in the years 2002-2003 we recorded the individuals that started reproduction and the number of generative shoots produced by each individual. The number of generative shoots was assumed as a measure of individual fertility. Two types of generative shoots were taken into consideration: those with unisexual spikes and bisexual spikes.

\section{Statistical analysis}

Differences between populations were tested using oneway analysis of variance (ANOVA). The variables in which differences were found to be significant were further analysed by Tukey post-hoc test. Kruskal-Wallis test was used to analyse the differences between populations in the number of generative shoots per individual and in the number of ramets per seedling due to the lack of a normal distribution of these variables.

\section{RESULTS}

\section{Area, abundance, reproduction}

Population C (Turzany) occupies the largest area of 20 $\mathrm{m}^{2}$, population B (Jacewo) occupies $17 \mathrm{~m}^{2}$ and population A (Dulsk) occupies only $4 \mathrm{~m}^{2}$. The number of individuals varied from 46 in population $\mathrm{C}$ and 43 in population $\mathrm{B}$ to 13 in population $\mathrm{A}$. The greatest number of generative shoots was produced by individuals from population B (1882 shoots), then those from population C (1372 shoots) and population A (390 shoots) (Kruskal-Wallis test: $\mathrm{N}=102$; $\mathrm{H}=16,42 ; \mathrm{p}<0.001)$.

\section{Size of utricles and fruits}

Individuals from different populations differed significantly in length of the utricles produced (ANOVA; $\mathrm{df}=2$, $67 ; \mathrm{F}=22.02 ; \mathrm{p}<0.00)$. The utricles produced by individuals from population $B$ were significantly shorter than those produced by plants from populations C (Tukey test $\mathrm{p}<0.001$ ) and $\mathrm{A}$ (Tukey test $\mathrm{p}<0.001)$, whereas there were no significant differences in utricle length between plants from populations C and A (Tukey test NS). Analysis of the other variables showed no differences between populations (utricle width - ANOVA; df=2, 67; F=0.178; NS; fruit length - ANOVA; $\mathrm{df}=2,67 ; \mathrm{F}=0.502 ; \mathrm{NS}$; fruit width ANOVA; $\mathrm{df}=2,67 ; \mathrm{F}=0.188 ; \mathrm{NS})$.

\section{Seed germination and seedling size}

The seeds started germinating after 6 months rest. The first seedlings were observed in the first decade of May. The greatest proportion of germinating seeds was noted in population B and the lowest in population A (Fig. 4B). Statistically significant differences between the populations were found as far as the length of the seedling was concerned (ANOVA; df=2.177; F=18.68; p<0.001) (Fig. 4c). The seedlings of population $\mathrm{B}$ were statistically longer than those of populations A and C (Tukey test $\mathrm{p}<0.001$ ), while no statistically significant differences in this variable were observed between populations A and C. The statistical analysis revealed also statistically significant differences be-
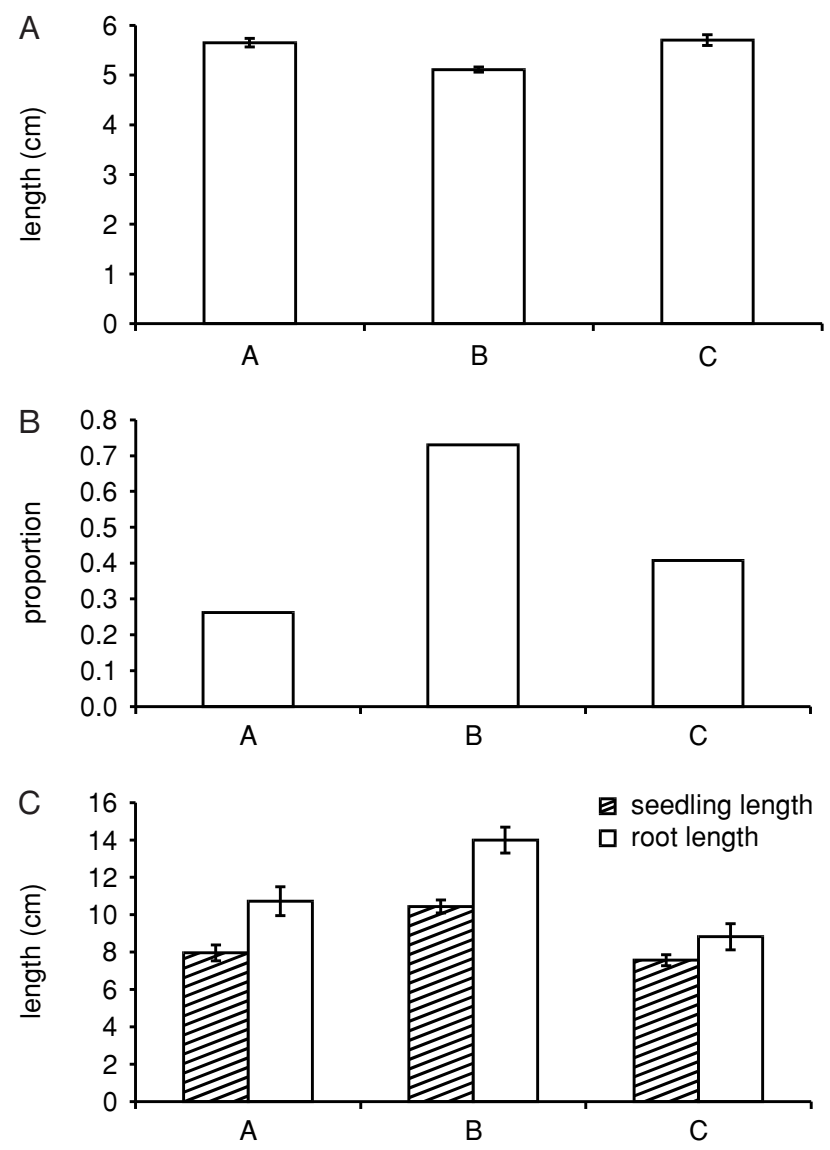

Fig. 4. The mean size of seeds and seedlings of Carex secalina in an inland saline in Poland: A - mean size of bubbles, $\mathrm{B}$ - proportion of germinating seeds, $\mathrm{C}$ - mean length of seedlings. 

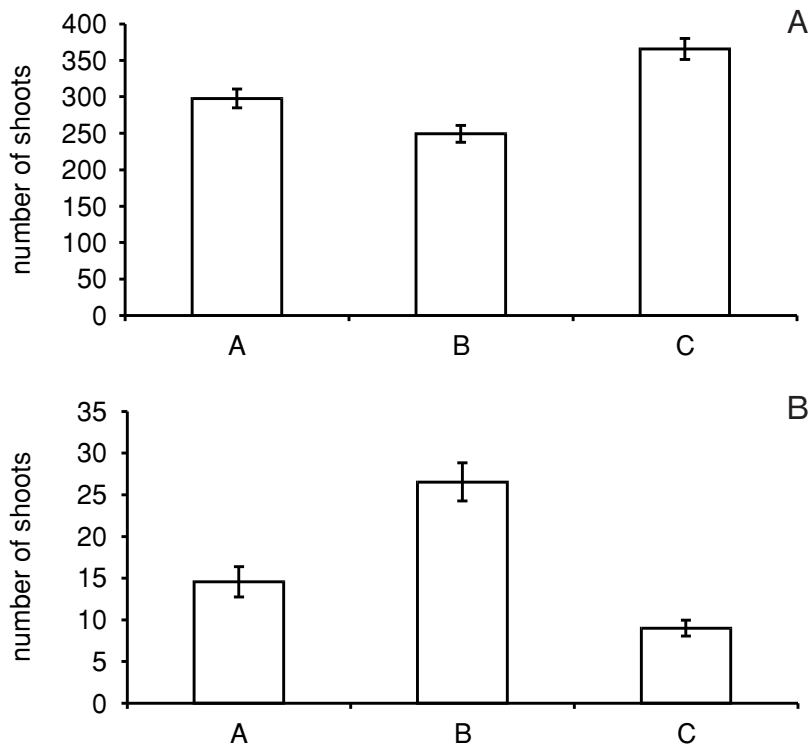

Fig. 5. The fertility of Carex secalina in the garden: A - mean production of generative shoots from unisexual spikes, B - mean production of generative spikes from bisexual spikes.

tween the populations in the length of the seedling root (ANOVA; $\mathrm{df}=2.177 ; \mathrm{F}=13.14 ; \mathrm{p}<0.001$ ) and the number of the seedling ramets (Kruskal-Wallis test: $\mathrm{N}=180 ; \mathrm{H}=42.32$; $\mathrm{p}<0.001)$. The seedlings from population B had statistically significantly longer roots than those of the seedlings from populations $\mathrm{A}$ and $\mathrm{C}$ (Tukey test $\mathrm{p}<0.01)$ with no difference in this variable between populations $\mathrm{A}$ and $\mathrm{C}$. As to the number of ramets the seedlings from population B produced their greatest number.

\section{Fertility of individuals and age of starting reproduction}

No individual started reproduction in the first year of life. The first generative shoots appeared in two individuals from population $\mathrm{C}$ in the second year of life. All individuals from the three populations produced generative shoots in the third year of life. Statistically significant differences were found between the populations in the production of shoots' unisexual spikes (ANOVA; df=2, 87; $\mathrm{F}=20.39$; $\mathrm{p}<0.001$ ) and bisexual ones (ANOVA; $\mathrm{df}=2,87 ; \mathrm{F}=25.65$; $\mathrm{p}<0.001$ ) (Fig. 5). In population B the proportion of shoots with unisexual spikes was lower than in populations $\mathrm{A}$ (Tukey test $\mathrm{p}<0.05$ ) and $\mathrm{C}($ Tukey test $\mathrm{p}<0.001)$. In the same population the proportion of generative shoots with bisexual spikes was the greatest (Tukey test $p<0.001$ ). In population $\mathrm{B}$ the number of shoots with unisexual spikes was lower than in population A (Fig. 5) and C, and this number in population $\mathrm{A}$ was lower than that in population $\mathrm{C}(\mathrm{p}<0.01)$.

\section{DISCUSSION}

The populations of Carex secalina can be classified as island, marginal and isolated populations occurring at the limit of the range. The results of the field study and garden observations are expected to enable answering the questions: (1) whether the occurrence of $C$. secalina in small and isolated populations within the whole range, including Poland, is a result of the taxon's withdrawal or should be considered in terms of the population dynamics within the geographical range of this species, (2) what is the origin of these populations and especially the one in the locality never before reported in literature (seed bank or new diaspores).

Reduction of variation in the marginal populations relative to that in central ones has been shown by many authors (Barrett and Kohn 1991; Barrett and Husband 1992; Reinhammar 1999; Stenstrom 1999; Jonsson and Prentice 2000). It is a consequence of the classical phenomena such as the bottleneck effect, the founder effect, inbreeding, genetic drift (Mitka 1997; Le Core and Kremer 1998). The studies have also shown the loss of ability of sexual reproduction to the advantage of asexual reproduction (Stenstrom 1999; Olejniczak 2001).

In the studied $C$. secalina populations the dominant are a few-year old individuals. Their exact age is unknown, however, on the basis of our results from the garden experiment, we know that the individuals starting sexual reproduction are at least 3 year old. Each individual from the populations in the field and from the garden started sexual reproduction. The production of generative shoots with unisexual spikes (typical of the species) and bisexual spikes (not noted for the species before) was high. The question arises, why, given such a high fertility of $C$. secalina individuals, its populations do not enlarge their areas. The hypothesis of the seeds unable of germination is rejected as we have established that $C$. secalina have a high germination ability relative to the other Carex species (Schütz and Milberg 1997; Schütz and Rave 1999; Schütz 2000). In view of the above it is striking not to find seedlings of this species. Two possible reasons have been suggested: (1) the seeds germinate, but the seedlings do not reach further stages of development because of a strong competition of other species or the seedlings are totally grazed by cattle before they reach a certain size, or (2) the seeds in the field are damaged or cannot germinate because of high salinity of the soil.

Best germination of halophytic grasses is obtained under nonsaline conditions and their germination decreases with increases in salinity (Noe and Zedler 2000; Khan and Gulzar 2003). Germination of grasses is usually inhibited at concentrations ranking from 250 to $350 \mathrm{mmol} / \mathrm{L} \mathrm{NaCl}$ (Lombardi et al. 1998). The salinity of the habitat in which $C$. secalina occurs has significantly increased relative to that in the beginning of the 20th century. This increase has been a result of the activity of the soda production plant. One of the habitats - the pasture is frequently flooded with the saline waters from this plant. However, the hypothesis of the inhibiting effect of soil salinity on seed germination needs experimental verification.

There are literature reports claiming that periods of local presence and disappearance (rapid decrease in abundance) are characteristic of marginal populations (Barrett and Kohn 1991). The situation with $C$. secalina in Poland was probably caused by a periodical disappearance of the population in the area of Poland. In 2000 the found populations were probably in the period of reappearance in these localities. A very interesting question was the origin of these populations, so the source of seeds from which the population recovered. In our garden experiment we have established that $C$. secalina individuals produce a great number of seeds capable of germination. Some of them do not germinate because of a high concentration of salt, but some are pre- 
served making a permanent seed bank. In suitable circumstances, e.g. a decrease in salinity, the seeds from the seed banks can start germinating leading to the population renewal. Longevity is characteristic of many plant species. A spectacular experiment confirming this was performed by Beal (1886) in the end of the 18th century. The seeds of different plant species were buried in containers in the soil. Every ten years some of them were taken out and their germination ability was tested. The seeds stored for 120 years were proved to be still able to germinate (Talewski and Zeevart 2002). The seeds of sedges belong to long-lived ones. The seeds of $C$. pilulifera were reported viable for over 85 years (Granström 1988) and even for over 130 years (Kjellson 1992). Thus formation of a permanent seed bank, often at considerable depths, permits the appearance of seedlings and the renewal of a population even after two to seven decades, if only the seeds remain viable. The removal of the upper soil level leads often to the reappearance of a population of a species not present on the surface.

In conclusion, it is definitely a reason for joy to note the presence of a species generally considered hitherto as extinct. The important thing however, is to recognise the biology of such a species, in particular the key processes in the life history of the species such as seed germination, seedling growth and reproduction. The information is necessary to be able to develop effective methods of its protection. As follows from our study, the species has adapted to variations in salinity of the soil. It undertakes sexual reproduction and produces many seeds capable of germination. Most probably the renewal of populations happens in the periods of decreasing salinity of the soils in particular habitats. Unfortunately, we are still not able to answer a number of questions posed in relation to the species, among others the question whether the occurrence of $C$. secalina in small and isolated populations within the whole range, including Poland, is a result of the taxon's withdrawal, or should be considered in terms of population dynamics within the geographical range of this species. An attempt at answering this question would require integrated ecological and genetical study.

\section{ACKNOWLEDGEMENTS}

This work was supported by grant (no. 3P04G 05524) the State Committee for Scientific Research in Poland.

\section{LITERATURE CITED}

BARRETT C.H., KOHN J.R. 1991. Genetic and evolutionary consequences of small population size in plants: implications for conservation. In: Genetic of conservation of rare plants. Falk D.A., Holsinger K.E. (eds). Oxford University Press, Oxford, pp. 3-30.

BARRETT C.H., HUSBAND B.C. 1992. The genetics of plant migration and colonization. In: Plant population genetics breedings and genetic resources. Brown A.H.D, Cleg M.T., Kahler A.L. (eds). Sunderland, MA, Sinauer, pp. 254-279.

BEAL W.J. 1886. The vitality of seeds buried in the soil. Proceedings of the Society for the Promotion of Agricultural Science 3: 14-15.

BOCK W. 1908. Taschenflora von Bromberg (Das Netzegebiet). Mitteler'sche Buchhandlung, 214 pp.
CHMIEL J., LEMBICZ M., ŻUKOWSKI W. 2001. Carex secalina Willd. ex Wahlenb. - turzyca żytowata, pp. 508-510. In: Polska Czerwona Księga Roślin. Paprotniki i rośliny kwiatowe. Polish Red Data Book of Plants. Pteridophytes and flowering plants. Zarzycki K., Kaźmierczakowa R. (eds). Instytut Botaniki im. W. Szafera PAN, Instytut Ochrony Przyrody PAN. Polish Academy of Sciences W. Szafer Institute of Botany, Institute of Nature Conservation, Kraków. (in Polish with English summary)

EGOROVA T.V. 1999. The sedges (Carex L.) of Russia and adjacent States (within the limits of the former USSR), St. Petersburg State Chemical-Pharmaceutical Academy, St. Petersburg; St. Louis Missouri Botanical Garden Press, St. Louis.

GRANSTRÖM A. 1988. Seed banks at six open and afforested heathland sites in southern Sweden. J. Appl. Ecol. 25: 297-306.

HOLUB J., PROCHÁZKA F. 2000. Red list of vascular plants of the Czech Republic. Preslia 72: 187-230.

JONSSON B.O., PRENTICE H.C. 2000. Allozyme diversity and geographic variation in the widespread coastal sedge, Carex arenaria. Diversity and Distributions 6: 65-80.

KHAN M.A., GULZAR S. 2003. Light, salinity, and temperature effects on the seed germination of perennial grasses. Am. J. Bot. 90 (1): 131-134

KJELLSON G. 1992. Seed banks in Danish deciduous forests, species composition, seed influx and distribution patterns in soil. Ecography 15: 86-100.

LE CORRE V., KREMER A. 1998. Cumulative effects of founding events during colonization on genetic diversity and differentiation in an island and stepping stone model. J. Evol. Biol. 11: 495-512.

LOMBARDI T., FOCHETTI T., ONNIS A. 1998. Germination of Briza maxima L. seeds: effects of temperature, light, salinity and seed harvesting time. Seed Sci. Techn. 26: 463-470.

LUDWIG G., SCHNITTLER M. (eds). 1996. Rote Liste gefändeter Pflanzen Deutschlands. Schriftenreiche für Vegetationskunde H. 28. Bundesamt für Naturschutz, Bonn-Bad Godesbeg.

MAGLOCKÝ S., FERAKOVÁ V. 1993. Red list of ferns and flowering plants (Pteridophyta and Spermatophyta) of the flora of Slovakia (the second draft). Biológia (Bratislava) 48 (4): 361-385.

MEUSEL H., JÄGER E., WEINERT E. 1965. Vergleichende Chorologie der Zentraleuropäischen Flora. Bd. I. G. Fischer Verlag., Jena.

MITKA J. 1997. Small, isolated plant populations at geographical range borders - some ecological and genetic processes. Wiad. Bot. 41 (2): 13-34. (in Polish)

MYERS N., MITTERMEIER R.A., MITTERMEIER C.G., DE FONSECA G.A., KENT J. 2000. Biodiverisity hotspots for conservation priorites. Nature 403: 853-858.

NOE G.B., ZEDLER J.B. 2000. Different effects of four abiotic factors on the germination of salt marsh annuals. Am. J. Bot. 87: 1679-1692.

OLEJNICZAK P. 2001. Evolutionary stable allocation to vegetative and sexual reproduction in plants. Oikos 95 (1): 156-160.

PURVIS A., HECTOR A. 2000. Getting the measure of biodiversity. Nature 405: 212-219.

REINHAMMAR L.G. 1999. Allozyme differentiation between the lowland Carex capitata and he alpine Carex arctogena (Cyperaceae) in Scandinavia. Biol. J. Linn. Soc. 67 (3): 377-389.

SCHÜTZ W. 2000. Ecology of seed dormancy and germination in sedges (Carex). Urban \& Ficher Verlag. Vol. 3/1. pp. 67-89.

SCHÜTZ W., MILBERG P. 1997. Seed dormancy in Carex canescens - regional differnces and ecological consequences. Oikos 78 (3): 420-428.

SCHÜTZ W., RAVE G. 1999. The effect of cold stratification and light on the seed germination of temperat sedges (Carex) from various habitats and implications fr regenerative strategies. Plant Ecology 144: 215-230.

STENSTROM A. 1999. Sexual reproductive ecology of Carex bigelowii, an arctic-alpine sedge. Ecography 22 (3): 305-313. 
TELEWSKI F.W., ZEEVAART J.A.D. 2002. The 120-yr period for Dr. Beal's seed vabillity experiment. Am. J. Bot. 89 (8): 1285-1288.

URBAŃSKI J. 1930. Rezultaty wycieczek florystycznych po Wielkopolsce wraz z projektami ochrony stanowisk rzadkich roślin. Wyd. Okr. Kom. Ochr. Przyr. na Wielkopolskę i Pomorze 1: 37-46. (in Polish)

WILKOŃ-MICHALSKA J. 1963. Halofity Kujaw. Stud. Soc. Sc. Tor., Sect D 7 (1), Toruń, 122 pp. (in Polish)

WODZICZKO A., KRAWIEC F., URBAŃSKI J. 1938. Pomniki i zabytki przyrody Wielkopolski. Wyd. Okr. Kom. Ochr. Przyr. na Wielkopolskę i Pomorze 8: 313-360. (in Polish with English summary)

ZAJĄC A., ZAJĄC M. 1993. Carex secalina Willd. ex Wahlenb. - turzyca żytowata. s. 250-251. In: Polska Czerwona Księga Roślin. Paprotniki i rośliny kwiatowe. Polish Plant Red Data Book. Pteridophyta and Spermatophyta. Zarzycki K., Kaźmierczakowa R. (eds). Instytut Botaniki im. W. Szafera PAN, Instytut Ochrony Przyrody PAN. Polish Academy of Sciences
W. Szafer Institute of Botany, Institute of Nature Conservation, Kraków.

ZARZYCKI K., SZELĄG Z. 1992. Czerwona lista roślin naczyniowych zagrożonych w Polsce. Red list threatened vascular plants in Poland. In: Lista roślin zagrożonych w Polsce. List of threatened plants in Poland. Zarzycki K., Wojewoda W., Heinrich Z. (eds). Instytut Botaniki im. W. Szafera PAN, Kraków, pp. 87-98.

ŻUKOWSKI W., JACKOWIAK B. 1995. Lista roślin naczyniowych ginących i zagrożonych na Pomorzu Zachodnim i w Wielkopolsce. List of endangered and threatened vascular plants in Western Pomerania and Wielkopolska (Great Poland). In: Ginące i zagrożone rośliny naczyniowe Pomorza Zachodniego i Wielkopolski. Endangered and threatened vascular plants of Western Pomerania and Wielkopolska. Żukowski W., Jackowiak B. (eds), Prace Zakładu Taksonomii Roślin UAM w Poznaniu nr 3. Publications of the Department of Plant Taxonomy of the Adam Mickiewicz University in Poznań No 3, Bogucki Wydawnictwo Naukowe, pp. 11-96. 